NBER WORKING PAPER SERIES

\title{
MILITARY POSITIONS AND POST-SERVICE OCCUPATIONAL MOBILITY OF UNION ARMY VETERANS, 1861-1880
}

\author{
Chulhee Lee \\ Working Paper 12416 \\ http://www.nber.org/papers/w12416 \\ NATIONAL BUREAU OF ECONOMIC RESEARCH \\ 1050 Massachusetts Avenue \\ Cambridge, MA 02138 \\ July 2006
}

I thank Dora Costa, Robert Margo, Werner Troesken, the participants of the 2004 NBER EI-CS Joint Conference and the 2006 ASSA meetings, and two anonymous referees of Explorations in Economic History for their helpful comments and suggestions, and Thomas Chappelear for his editorial assistance. I gratefully acknowledge financial support from the National Institute on Aging, the National Institutes of Health (P01 AG10120). The views expressed herein are those of the author(s) and do not necessarily reflect the views of the National Bureau of Economic Research.

(C)2006 by Chulhee Lee. All rights reserved. Short sections of text, not to exceed two paragraphs, may be quoted without explicit permission provided that full credit, including $($ ) notice, is given to the source. 
Military Positions and Post-Service Occupational Mobility of Union Army Veterans, 1861-1880

Chulhee Lee

NBER Working Paper No. 12416

July 2006

JEL No. J24, J5, N3

\begin{abstract}
Although the Civil War has attracted a great deal of scholarly attention, little is known about how different wartime experiences of soldiers influenced their civilian lives after the war. This paper examines how military rank and duty of Union Army soldiers while in service affected their post-service occupational mobility. Higher ranks and non-infantry duties appear to have provided more opportunities for developing skills, especially those required for white-collar jobs. Among the recruits who were unskilled workers at the time of enlistment, commissioned and non-commissioned officers were much more likely to move up to a white-collar job by 1880 . Similarly, unskilled recruits who had served on white-collar military duties were more likely to enter a white-collar occupation by 1880 . The higher occupational mobility of higher-ranking soldiers is likely to have resulted from disparate human capital accumulations offered by their military positions rather than from their superior abilities.
\end{abstract}

Chulhee Lee

Department of Economics

Seoul National University

San 56-1, Silim-Dong Kwanak-Gu

Seoul 151-742

SOUTH KOREA

and NBER

chullee@snu.ac.kr 


\section{Introduction}

The Civil War was the biggest military conflict the United States has ever experienced in terms of the proportion of the population directly involved. More than 3,000,000 men-including nearly 2,000,000 whites and 189,000 blacks who fought for the Union, and 900,000 men who joined the Confederate forces-served in the armed forces. In the North and South combined, about $40 \%$ of whites of military age (ages 13 to 43 in 1860) served in the military. The Civil War was also the bloodiest event in American history. About 618,000 Union and Confederate soldiers and sailors, or 182 individuals per 10,000 population, died during the Civil War. The number of military deaths for the Civil War exceeds by more than $50 \%$ the military deaths in World War II, during which about 405,000 servicemen were killed (Vinovskis 1990). ${ }^{2}$ Furthermore, a large number of survivors returned home either wounded or debilitated by illness. ${ }^{3}$

As befits its historical significance, the Civil War has drawn a great deal of scholarly attention, perhaps more than any other event in American history. The economic impact of the Civil War, the broad theme of this study, has also been of perennial interest to economic historians. ${ }^{4}$ However, the differing effects of the Civil War on individuals and the reasons for these differences have been much less explored. In particular, very little is known about how disparate wartime experiences of soldiers influenced their civilian lives after the war. ${ }^{5}$ Since a majority of the younger male cohorts circa 1860 served in the military forces during the Civil War, a better understanding of the effect of military service on civilian life would have broad implications for postbellum U.S. economic history in general.

As part of an effort to understand the socioeconomic impact of military service

\footnotetext{
${ }^{2}$ Military deaths per 10,000 population for the Civil War were 182 individuals, much higher than 118 men for the American Revolution and 30 persons for World War II.

${ }^{3}$ One in four Union Army soldiers was wounded and two-thirds of them suffered from disease at least once while in service (Steiner 1968).

${ }^{4}$ Goldin and Lewis (1975), for example, estimated that the total direct cost of the Civil War in 1860 dollars was $\$ 3.4$ billion for the Union and $\$ 3.3$ billion for the Confederacy.

5 The lack of literature on this issue is well described by Maris Vinovskis (1990, pp. 1-2): "Very little has been published on civilian life in the North or the South during the war years, and almost nothing is available on the postwar life course of Civil War veterans."
} 
during the Civil War, this paper examines how the military rank and duty Union Army veterans held while in service affected their post-service occupational mobility. It is often acknowledged that military service provides on-the-job training to servicemen. As determinants of role, authority, and responsibility, rank and duty should greatly influence the human capital accumulations of soldiers while in service. For the majority of the recruits who served on infantry duty at the lowest rank, military service may have merely interrupted their accumulation of human capital. On the other hand, higher ranks and noninfantry duties may have provided more opportunities for developing the kinds of skills they would have received while being employed in a civilian job. In particular, for the recruits who had no previous experience leading other people, serving as an officer in the army may have offered a good opportunity to develop communication, management, coordination, and decision-making skills while carrying out their responsibilities. Similarly, unskilled enlistees assigned to military duties similar to skilled or white-collar civilian jobs could have been able to master new skills while in service. My study will offer evidence to determine whether this was the case.

A number of recent studies suggest that the experience of war radically changed the course of veterans' lives. Wounds and diseases suffered by Union Army veterans while in service diminished their wealth accumulations and geographic mobility, perhaps by lowering their physical productivity (Lee 2005a, 2005b). The wartime experience of being deployed into distant regions increased veterans' post-service geographic mobility, probably by offering them more information on other places and reducing psychological resistance to moving to a new territory (Lee 2005b). Deserters, especially those from prowar communities, were more likely to move out of their home states than non-deserters, perhaps because of shame and ostracism (Costa and Kahn 2004b). The war experience of serving with a more heterogeneous group of peers had a favorable effect on black Union Army soldiers' economic mobility after the war (Costa and Kahn 2004a). My study will contribute to this line of research by examining the effect of a previously unexplored aspect of military service, namely, different wartime human capital accumulations.

My study will also contribute to the contemporary literature on the labor-market 
impact of military service. The major focus of the literature produced so far has been to estimate the differences in employment and earnings between veterans and non-veterans, correcting for the potential selection bias arising from the fact that veterans are both selfselected and screened by the military (Angrist 1990; Angrist and Krueger 1994; Angrist 1998). In contrast to the considerable research interest in the differences in economic outcomes between veterans and non-veterans, the variation in post-service labor-market experiences across veterans has been much less explored. Military service is by no means a homogeneous experience for all servicemen. The degree of risk and the quality of on-thejob training while in service differ greatly between soldiers depending on their duty, rank, and the military missions their unit is given. This paper fills this gap in the literature.

\section{Data}

This study is based on a sample of several primary data sources that were collected and linked as part of the project "Early Indicators of Later Work Levels, Disease, and Death," jointly sponsored by the National Bureau of Economic Research, the National Institutes of Health, the Center for Population Economics at the University of Chicago, and Brigham Young University. The original population from which the sample used in this study was drawn is composed of 35,747 recruits enlisted in 331 randomly selected Union Army companies. These recruits have been linked to various data sources, such as military service records, pension records, and records from the 1850, 1860, 1900, and 1910 censuses. $^{6}$

The service records contain very detailed descriptions of the diseases or wounds that the recruits suffered, together with the ultimate outcome, such as return to service, discharge for disabilities, or death (U.S. Surgeon General's Office 1870, vol. 1). They also provide information on the demographic and socioeconomic characteristics of recruits prior to enlistment, including age, occupation, place of birth, and height, as well as details of

\footnotetext{
${ }^{6}$ See Fogel (1993, 2000a, 2000b, 2001) and Wimmer (2003) for more detailed explanations of the Early Indicators Project and data produced therefrom. The data sets collected and linked as part of this project can be obtained from the web site of the Center for Population Economics (http://www.cpe.uchicago.edu).
} 
their military career, including rank, military duty, company, regiment, change in military status, dates of enlistment and discharge, and so on.

For the purpose of examining the patterns of economic mobility after the Civil War, the recruits were located in and linked to the manuscript schedules of the 1880 population census. The search was restricted to 20,315 men who had not died before the 1880 census was enumerated (including those whose subsequent death dates are unknown) and for whom information on some basic characteristics such as birth place and age at enlistment was given. As a result of the linkage process, 7,229 veterans were successfully linked to the 1880 census, or $36 \%$ of those searched. ${ }^{7}$ The sample was further restricted to 6,882 men who were aged 18 to 45 at enlistment. The samples linked to the 1880 census are largely similar to the entire Union Army in terms of personal characteristics and wartime medical experiences. It is thus likely that the results of this study generally represent the experiences of the entire Union Army. ${ }^{8}$

\section{Recruitment and Organization of the Union Army}

When the American Civil War broke out, both the Union and Confederate governments were totally unprepared for a large-scale military campaign. ${ }^{9}$ Prior to the outbreak of the war, the U.S. had maintained only a small number of armed forces, fewer than 16,000 men, many of them stationed on the Western frontier. In the early years of the war, under the influence of the old Revolutionary-era militia act and a long-standing tradition of volunteerism, the recruitment and organization of the troops were initiated by states or localities in a decentralized manner. ${ }^{10}$ Prominent local citizens opened recruiting

${ }^{7}$ See Costa and Kahn (2004b) for more detailed descriptions of the sample.

8 See Lee (2005a, 2005b) for a more detailed discussion of potential sample selection bias.

${ }^{9}$ For the history of the recruitment and organization of the Union and Confederate armed forces see Shannon (1928); Murdock (1971); McPherson (1982, 1988); Vinovskis (1990); and Geary (1991).

${ }_{10}$ The militia act of May 8, 1792 authorized the enrollment of all able-bodied men between the ages of eighteen and forty-five for service in local militia companies. The president was not empowered to call the militia into federal service. The militia act of February 28, 1795 explicitly authorized the president to order the militia into federal service for suppressing internal rebellion or for repelling foreign invasion. Permission from the legislatures of the affected states was required, or if they were not in session, from the respective governors (Geary 1991, xiv). 
offices and organized recruiting rallies, sponsored bond rallies, and held concerts and exhibitions in an effort to raise bounty money to be paid to volunteers. When approximately one hundred men had signed up, they were formed into a company. During the first two years of the war, the Union could recruit a sufficient number of volunteers. Out of patriotism, local pride, expectation of a short-term campaign, and romantic notions of what war was like, men rushed to enlist before the war was over.

It was only after the Militia Act was enacted in July 1862, particularly after the Enrollment Act was approved in March 1863, that national drafting in the North began. ${ }^{11}$ By 1862, a sense of duty and the desire to enlist with men from their hometowns were the dominant factors that prompted volunteers to enlist in the armed forces. However, the summer of 1862 inaugurated a period of competitive bidding for recruits, and from that point on the sense of patriotism gradually diminished as a spur to volunteer enlistment. As the reservoir of manpower began to evaporate at home, many townships and other political subdivisions retained brokers to canvass other geographical areas for manpower to fill their quotas. During the second half of the war, bounties and the threat of conscription (in case the quota was not met) had a combined influence on volunteering, and the percentage of draftees increased over time.

In appointing officers, especially those at the top, War Department officials tried to recruit experienced and capable persons such as former officers, Mexican War veterans, or West Point professionals. In raising an army of more than a million men, however, it was clearly impossible to furnish officers with such training for all positions. Accordingly, a large number of commissioned officers and most lower-rank non-commissioned officers were recruited from a pool of amateur volunteers. In the early stages of recruitment, it was common that men in companies elected the company officers (captain and lieutenants), and these in turn elected the regimental officers (colonel, lieutenant colonel, and major). ${ }^{12}$ The

\footnotetext{
${ }^{11}$ The Militia Act of 1862 required the enrollment of all male citizens between the ages of eighteen and forty-five for the future draft calls of their respective governors, and it extended the president's power to issue quotas based on population. The Enrollment Act of 1863 further affirmed "the power of the national government to 'raise and support armies' without state assistance." See Geary (1991), chapters 4 to 6 .

12 According to James McPherson (1988, p. 318), "the election of officers was often a pro forma
} 
state governors officially commissioned the regimental officers but usually appointed those elected by company officers.

As the war progressed, however, recruitment and organization of the Union Army became increasingly centralized and standardized. Recognizing the need for minimum standards of officer competence, the Union Army instituted an examination for officers in July 1861. Promotion within the ranks of old regiments was generally earned by merit, not election. By 1863, the Union Army had virtually ended the practice of electing officers.

Whether it was by election or by appointment, there certainly were strong incentives among both officers and enlisted men to select a qualified person for highranking positions. It is not difficult to find anecdotal stories showing that political and military leaders of the Union were keen to appoint competent commanding officers suitable for the positions. Though not recorded as often as these high-profile cases, it is likely that commanding officers also tried to appoint the best people for lower-ranking officer positions. Lee (1999) found that a recruit who possessed the skills and abilities required for making a capable officer was more likely to be appointed a non-commissioned officer at the time of enlistment and promoted to higher ranks in the course of service. Likewise, a particular non-infantry duty tended to be given to a recruit who had been employed in a job similar to the duty, perhaps to reduce training costs. ${ }^{13}$

Some features of the Union Army recruitment system, such as furnishing substitutes and paying commutation in place of service, have been blamed for producing an unequal burden of military service and casualties across different social classes. This claim, often referred to as a "rich man's war and poor man's fight," has drawn a great deal of attention from social historians (Murdock 1964; Levine 1981; Rorabaugh 1986; Kemp 1990; Geary 1991). In addition to the argument that lower-class men were more likely to enlist, Vinovskis (1990) suggested that, even among soldiers, men from disadvantaged

ratification of the role that a prominent planter, lawyer, or other individual had taken in recruiting a company or a regiment." For example, a rich person often paid for the uniforms and equipment of a unit he had recruited and became its commanding officer.

13 The study by Lee (1999) is based on a sample of Union army soldiers who enlisted in the state of Ohio. A recent unpublished study by the author based on a much larger and geographically more balanced sample confirms that this result is generally true for the entire Union army. 
backgrounds were more likely to die or to be wounded than those who had higher-ranking jobs or greater wealth, presumably because they were more susceptible to disease or were sent on more dangerous missions. Though not completely resolved yet, the validity of this "poor man's war" thesis appears doubtful in light of some recent quantitative evidence. Despite the well-known episodes about draft riots, bounty jumpers, and substitutes, the vast majority of the Union Army soldiers were volunteers who joined the military from a wide socioeconomic spectrum of the American North. ${ }^{14}$

\section{Rank, Military Duty, and Post-Service Occupational Mobility}

As suggested above, the type and quality of human capital accumulations of Union Army soldiers probably differed greatly by rank and duty. In the balance of this paper, I examine whether the potential disparities in on-the-job training while in service offered by different military positions affected the veterans' post-service occupational mobility-one of the most important dimensions of socioeconomic mobility in the nineteenth century, along with wealth accumulation and geographic mobility.

As the measure of occupational mobility, I consider the probability that persons employed in unskilled occupations (including tenant farmers) at the time of enlistment moved up to farming, skilled, or white-collar occupations by 1880 . The probability of occupational improvement among the unskilled is a widely used measure of economic mobility in the nineteenth century (Thernstrom 1964, 1973; Bodnar 1985; Ferrie 1999). ${ }^{15}$

${ }^{14}$ Drafted men and substitutes account for, respectively, $3 \%$ and $6 \%$ of nearly 36,000 men in the entire Union army sample. The sample of Union army soldiers was generally similar to the random sample of the entire male population of military age in terms of occupational composition and wealth holding (Fogel 1993). Soldiers from a healthier living environment (such as farmers and residents in rural areas) were more likely to contract and die from disease while in service than those who had lived under more unfavorable conditions (such as non-farmers and city dwellers) because of the different degrees of exposure to disease prior to enlistment (Lee 1997, 2003). Lee (1999) rejected the view that recruits from lower social classes were discriminated against in the assignment of military missions, suggesting that new enlistees were allocated to different positions so as to enhance the efficiency of each military unit.

${ }^{15}$ It has been found that the occupational mobility in the nineteenth-century U.S. measured in this way was relatively high, although varying across different places and populations. Between 1860 and 1879, more than a third of the unskilled in Boston moved up to either white-collar or skilled occupations (Thernstrom 1973). The same measure for Newburyport between 1860 and 1880 was 
Roughly 2,700 veterans who were employed in unskilled occupations at the time of enlistment and who were linked to the 1880 census were selected for this analysis.

Occupational change may be modeled as a type of investment in human capital to increase the present value of lifetime earnings. A recruit discharged from military service would have faced a choice between remaining in his previous occupation or moving to another job. Moving to a different occupation can bring a rise in lifetime income or social status, but at the same time incurs a cost of retraining. The chances that a person will switch occupations will depend on the anticipated net income gains over his remaining work life, discounted by his rate of time preference (Ferrie 1999). Rank and military duty while in service could affect a veteran's choice of civilian job after the service by altering the cost of retraining or the expected rise in income from a new occupation.

As measures of human capital accumulation of recruits while in service, I include a number of dummy variables indicating particular ranks and military duties. The ranks are classified into four categories: privates (control group); corporals; sergeants; and officers. In making this classification, I consider the highest rank a given soldier ever reached during his military service. Hence, these variables on rank contain information on both the initial assignment of rank and subsequent promotions. ${ }^{16}$ Military duties are divided into five categories: infantry and combat (including detached and unclassified duties); white-collar (including non-manual duties); skilled; unskilled manual; and musical duties. ${ }^{17}$

In addition to military position, I include variables on other human capital attributes such as health, age, and nativity, as determinants of the costs and benefits of retraining for occupational change. Older age is associated with a shorter remaining work

12\% (Thernstrom 1964, p.96). Among immigrants who entered the U.S. in the mid- nineteenth century, the probability of upward occupational change differed substantially by country of origin (Ferrie 1999). Intergenerational occupational mobility in the nineteenth-century U.S. was higher in both historical and comparative standards (Long and Ferrie 2005; Ferrie 2005).

${ }^{16}$ Higher-ranking commissioned officers are very rare in the sample because those who were commissioned officers in the first place were excluded from the collection of the data. 90\% of recruits were privates, the lowest rank, at the time of enlistment; nearly a quarter of the soldiers in the sample were promoted to a higher rank in the course of military service.

${ }^{17}$ I have made the classification of non-infantry duties as comparable as possible to the occupation categories used in this study. See Appendix Table 1 for the detailed classification of military duties. 
life; however, the cost of obtaining new skills could be lower for more experienced workers. Therefore, the impact of age on occupational mobility is ambiguous, depending on the relative magnitudes of the effect of age on the length of the benefit streams and the effect of age on the cost of changing occupations (Ferrie 1999). Immigrants may have faced greater difficulties in occupational mobility than natives because they had low skill levels, especially in terms of language proficiency; because the human capital obtained in their country of origin was not perfectly matched with that required in the United States; because they had small social networks; and because they were subject to discrimination in the labor market. In addition to these human capital variables, dummy variables on the region of enlistment were included to account for the possibility that the probability of occupational improvement was influenced by the conditions of the local labor market. Finally, I added dummy variables on the year of enlistment to account for the difference in the length of time a soldier was subject to occupational change by year of enlistment. ${ }^{18}$

Military service during the Civil War seriously damaged the physical and mental health of recruits who survived the war, which could have influenced their postwar occupational choice. As measures of wartime physical health, I use dummy variables indicating whether a veteran was wounded or suffered illnesses while in service. As an index of wartime stress, I use dummy variables indicating the four categories of the company's mortality from wounds: zero; $3 \%$ or less; $3 \%$ to $5 \%$; and more than $5 \%$ (denoted as Co wound mortality 1 through 4). The underlying assumption is that soldiers whose unit suffered higher casualties experienced more severe wartime stress. ${ }^{19}$ In addition to the variables on wartime experiences I have added variables on height at the time of enlistment as an indicator of the nutritional status of recruits. ${ }^{20}$

${ }^{18}$ For recruits who enlisted in 1861, for example, we observe occupational mobility for 19 years; for those who entered the army in 1865, on the other hand, we observe occupational change for only 15 years.

19 See Lee (2005a, 2005b) for more detailed explanations for the measures of physical health and wartime stress, and the pathways by which health affects economic mobility.

${ }^{20}$ Since it is inappropriate to compare the height of recruits who were still growing with those who had already reached their final stature, it is desirable to use an age-standardized measure of height. Accordingly, I construct five dummy variables on height (Height 1 to Height 5), each of which represents a quintile of the height distribution for a particular age. 
The results of the logistic regressions (presented in Table 1) suggest that rank and duty while in service had a strong effect on the probability that unskilled recruits moved up to white-collar occupations. Sergeants and officers were respectively $58 \%$ and $84 \%$ more likely to be employed in a white-collar job in 1880 than privates. A corporal's probability of moving to a white-collar occupation was not statistically different from a private's. Men who served on a white-collar duty while in service were more than twice as likely to move up to a white-collar job as infantrymen. The recruits who were musicians in the army also boasted much higher chances of switching to a white-collar occupation. ${ }^{21}$

For veterans who were either farmers or craftsmen in 1880, the correlation between military position and post-service occupational mobility is much weaker. The veterans who were corporals and those who served on skilled duties while in service were more likely to be employed in farming by 1880 than, respectively, privates and infantrymen. In general, however, higher-ranked soldiers and men assigned to white-collar or skilled duties had no strong advantages over privates and infantrymen in terms of the probability of becoming farmers or artisans after service. ${ }^{22}$

To summarize the regression results for other variables, measures of health had a relatively weak effect on occupational mobility. Wartime illnesses significantly diminished the probability that unskilled recruits would move to a white-collar occupation. In general,

${ }^{21}$ It is unclear why musicians had advantages in post-service occupational mobility. Given that their military duties were described as "Band," "Bugler," "Trumpeter," "Drummer," as well as "Musician," many of them probably played musical instruments in military bands. Playing musical instruments or working with other band members may have played a role of training useful for white-collar jobs. Another possible explanation is that musicians joined the army at younger age compared to men who served on other duties. The percentage of men under age 20 at enlistment was $37 \%$ for musicians, much higher than $25 \%$ for the entire sample. According to the result reported in Table 2, the favorable effect of serving on white-collar or musical duties on the probability of moving to white-collar occupations was particular strong for younger soldiers. Having military experiences serving on a non-combat duty earlier in the life-course could have been beneficial for their later labor-market career.

${ }^{22}$ Classification of occupation or military duty unavoidably entails judgment calls. Following the suggestion of a referee, I employed an alternative duty classification, including cooks, baker, and teamsters in the category of skilled duties. The result based on this new classification, not reported here, is very similar to the result reported in Table 1, although the negative effect of serving on a skilled duty on the probability of entering a skilled occupation became more statistically significant $(\mathrm{p}=0.119)$. 
the impact of diseases and wounds while in service on subsequent occupational choice was statistically insignificant. This outcome contrasts with the finding that wartime diseases and wounds severely diminished wealth accumulations and geographic mobility of the veterans (Lee 2005a, 2005b). Age at enlistment was negatively related to the probability of moving up to a white-collar job, whereas the chances of becoming a farmer increased with age. It appears that prior knowledge, skills, and wealth accumulation (all positively associated with age) were more important determinants of switching to farming, while the anticipated return to investment in retraining (negatively related to age) was a key factor in moving to a white-collar job. A native veteran was more likely than an immigrant to become a farmer. Not surprisingly, former tenant farmers were much more likely to become farmers by 1880 than non-farm unskilled workers. Height had no effect on occupational mobility. The probability of switching to farming was higher for the veterans who enlisted in the Midwest, presumably due to the greater availability of farmland in the region.

The observed relationship between military position and post-service occupational mobility may be interpreted in terms of differing human capital accumulations while in service. Higher-ranked soldiers such as sergeants and officers, for example, were perhaps given more opportunities to develop certain skills while performing their duties. Given that army officers' ordinary tasks involved some skills required for white-collar occupationssuch as communication, management, coordination, and decision-making-it makes sense that they had particularly strong advantages over lower-ranked soldiers in the probability of transferring to a white-collar job. An officer's military experiences should have served as on-the-job training that eventually reduced the cost of retraining required for moving to a white-collar occupation or increased the anticipated financial gains from the occupational change. However, corporals were probably too low-ranking to gain experience in leading soldiers. Similarly, serving on a white-collar military duty could have been a more direct path for obtaining skills required for white-collar jobs. For formerly unskilled workers who perhaps had no previous leadership experience, a military career should have been a valuable asset for their subsequent economic mobility.

Military experience in higher ranks and in some non-infantry positions probably 
offered training in general white-collar skills rather than specific skills which could subsequently be of marketable value in civilian life. As circumstantial evidence, Appendix Table 2 lists the 1880 occupations of the veterans who served either at a higher rank or on a non-infantry duty, and who moved up from an unskilled job to a white-collar occupation. Former commissioned and non-commissioned officers were engaged in a variety of whitecollar occupations that required general managerial and human relations skills rather than specific skills that could be offered by military experience. Similarly, military duty and post-service civilian occupations are not particularly well matched if finer classifications of duty and job are employed.

\section{Human Capital Hypothesis vs. Ability Hypothesis}

In light of the selective nature of the assignment of military positions, however, the results given above could be explained by the disparate abilities of recruits assigned to different ranks and duties. Lee (1999) suggests that enlistees who were appointed to a higher rank were perhaps more competent than privates, as indicated by their superior individual characteristics. Even within a group of recruits with the same observable characteristics, officers could have been more talented persons than privates. If this were indeed the case, some of the effect of military position on post-service occupational mobility may have resulted from disparities in ability prior to enlistment rather than differences by rank and duty in human capital accumulations. To put it differently, the association between military position and subsequent occupational mobility could merely reflect residual effects of the selective assignment of military positions not fully captured by the variables on personal characteristics included in the analysis.

I test these hypotheses in two ways. First, I examine how the effects of military position on occupational mobility differed by the length of military service and age at enlistment. The on-the-job training offered by a certain military position, if any, is likely to be positively related to the length of military service. On the other hand, a recruit's ability should be uncorrelated with the length of service. Hence, if the human capital hypothesis were true, the effects of military position on occupational mobility should be stronger for 
men who served longer terms. Likewise, the effect of training obtained while in service, if any, should differ by age, because age is an important determinant of the net return to investment in human capital. It is likely that the earlier the recruits were trained, the greater the difference in their subsequent occupational careers.

I perform the same logistic regressions as the one reported in the first column of Table 1 (correlates of the probability of moving up to a white-collar job) separately for the following four sub-samples: men who served for one to three years in the army; soldiers who served for less than one year in the army; recruits who were under 28 at the time of enlistment; and servicemen who were 28 or older at enlistment. The results, presented in Table 2, support the human capital hypothesis over the ability hypothesis. The effects of having a higher rank and of serving on a white-collar military duty on the probability of moving to a white-collar occupation were much stronger for the sub-samples of long-term servicemen and younger recruits than for the samples of short-term servicemen and older enlistees, respectively.

Secondly, the potential problem explained above can be treated as a bias arising from an omitted variable. If military rank while in service was positively correlated with unobserved ability, its effect on post-service occupational mobility estimated by the regressions conducted above should be overestimated. The most straightforward solution to this problem is to employ instrumental variable regression. If the effect of military rank on occupational mobility becomes insignificant or much weaker when estimated by an instrumental variable regression, it is likely that the ability hypothesis is a more plausible interpretation of the result than the human capital hypothesis.

For the purpose of this analysis, a legitimate instrumental variable should be correlated with the probability that a recruit was appointed or promoted to a higher rank, and uncorrelated with his ability. I chose the following two instrumental variables: the fraction of recruits in a given company who were given a higher rank at enlistment; and the fraction of recruits in a given company who were initially privates but were promoted to a higher rank in the course of military service. These two variables are measures of "demand" for higher-ranked personnel, which was determined by the type and severity of military 
missions assigned to a given company. A recruit who served in a company that suffered more casualties, for example, was more likely to be promoted because of more vacancies in higher ranked positions and more chances of proving one's valor in the line of fire. These variables, on the other hand, are unlikely to be correlated with a recruit's ability. Because residents of the same town were generally enlisted in same company, for example, it is unlikely that more talented recruits were sorted into high-risk companies.

I conduct logistic regressions to estimate the probability of holding a higher rank while in service, predicted by the instrumental variables introduced above. The results, not reported here, suggest that the selected instrumental variables are all strong predictors of the probability that a recruit was given a higher rank. As expected, the higher the demand for higher-ranked personnel in a given company - that is, the higher the percentage of recruits in a given company who were appointed to a higher rank at enlistment, or who were originally privates and promoted later-the greater the probability that recruits in the company had ever held a higher rank.

I then conduct a second-stage regression to examine the effect of holding a higher rank while in service on the probability that an unskilled recruit moved up to a white-collar job by 1880. Table 3 compares the result for instrumental variable estimation (Row 2) with that for a simple logistic regression (Row 1). Although omitted from the table, the same independent variables are used as those reported in Table 1, with the exception of the variables on company mortality and the year of enlistment. ${ }^{23}$

The result of the instrumental variable estimation shows that the predicted probability of holding a higher rank while in service significantly increases the measure of occupational mobility. The degree of significance for the predicted probability is similar to that for the simple regression. The magnitudes of estimated parameters (column 3) and of marginal effect (column 4) are much greater for the result of the instrumental variable

\footnotetext{
23 The variables on company mortality and the year of enlistment are excluded from the regressions because they are correlated with the company-specific variables employed in the first-stage regressions; and because the variables on company mortality are not significant at all in the simple regressions reported in Table 1.
} 
regression than for the simple regression. But the size of the coefficient may not be directly comparable because of the very different distributions of the dummy variable for and the predicted probability of holding a higher rank. As can be observed in Column 2 of Table 3, the standard deviation of the predicted probability is much smaller than that of the dummy variable because it is concentrated within narrow ranges. But even if such differences are taken into account, the coefficient of the instrumental variable regression is not smaller in magnitude than that of the simple regression. The size of the estimated parameter per one standard deviation (reported in Column 5 of Table 3) is slightly greater for the instrumental variable regression than for the simple regression. This result disproves the theory that higher-ranking soldiers experienced higher occupational mobility because they were more talented than those at lower ranks.

In sum, serving in the Union Army at a higher rank appears to have directly increased the probability that an unskilled veteran moved up to a white-collar occupation in the two decades following service. The relationship between military position and postservice occupational mobility is not merely an artifact of the selective assignment of rank and duty according to ability. Disparate human capital accumulations offered by different military positions are a more plausible explanation for this finding.

\section{Conclusions and Further Implications}

This paper has examined how military rank and duty while in service affected veterans' post-service occupational mobility. For the majority of the recruits who served on infantry duty at the lowest rank, military service should have merely interrupted their human capital accumulation. Higher ranks and non-infantry duties, on the other hand, may have provided more opportunities for developing skills similar to the training they would have received while being employed in a civilian job. Among the recruits who were unskilled workers at the time of enlistment, sergeants and officers were much more likely to move up to a white-collar job by 1880 than privates, holding other personal characteristics and military experiences constant. Similarly, unskilled recruits who had served on whitecollar military duties were much more likely to enter a white-collar occupation by 1880 . 
The effects of military rank and duty on post-service occupational mobility were much stronger for men who served longer in the army and for younger recruits than for short-term servicemen and older soldiers, respectively. An instrumental variable regression designed to correct the potential bias arising from omitted variables on ability produces a similar result. These results suggest that the observed relationship between military position and subsequent occupational mobility largely reflects differences in human capital accumulation while in service rather than disparate abilities.

This study suggests that the economic impact of military service differs among veterans depending upon their experiences while in service. I have reported elsewhere that the health and geographic mobility of Union Army veterans while in service varied greatly from person to person, and that these differences in wartime experiences strongly affected their wealth accumulation and geographical mobility after service (Lee 2003, 2005a, 2005b). This paper provides evidence that human capital accumulations of Union Army recruits differed considerably by rank and military duty. The health and human capital formation of a soldier could also be influenced by the type of military missions assigned to his unit (Lee 2005a) and the characteristics of the other servicemen with whom he served (Costa and Kahn 2004a). Hence, the impact of military service on civilian careers may vary widely. Military service could be a valuable opportunity to master new skills, widen one's perspective on the outside world, and build a new social network, or it could be a traumatic event that persistently damaged economic performance over the life course. For this reason, measuring the average effects of military service on post-service civilian lifethe main focus of existing studies-provides only a partial understanding of the socioeconomic impact of military service.

My study also suggests that military service affects particular types of skills differently. In the Union Army, different military positions had particularly powerful differential impacts on the recruits' training in white-collar skills. Though it cannot be directly determined based on the evidence given in the present paper, it is likely that the most important type of skills that the military provides to servicemen is general whitecollar skills. All new enlistees, regardless of rank and duty, have to adapt themselves to a 
military organization which is likely to be more strict and hierarchical than any civilian organization. Soldiers of all ranks must be properly trained to follow military rules, communicate with other soldiers, and perform their duties. Hence, for many young recruits, military service could serve as a basic training course for human relations or management. Such on-the-job training in the military should be particularly valuable to the recruits who are less skilled and who lack organizational experience. ${ }^{24}$

A comparison of measures of occupational mobility between the Union Army veterans and native-born white males in a random sample linked to the 1860 and 1880 censuses supports this conjecture. The probabilities that the unskilled moved up to the occupations of farmer and artisan between 1860 and 1880 were substantially lower for Union Army veterans than for the white male population at large. ${ }^{25}$ In contrast, unskilled Union Army veterans were much more likely to enter a white-collar job than unskilled nonveterans. Even the unskilled veterans who had not benefited from the training offered by a high-ranking position or a white-collar military duty boasted higher chances of entering a white-collar occupation than non-veterans. ${ }^{26}$

${ }^{24}$ For example, it is widely noted that military service during the Civil War was particularly beneficial for the civilian careers of ex-slaves who joined the Union Army. They gained new skills in regimental schools and a wider knowledge of the world in army service. In particular, black noncommissioned officers (along with the few commissioned ones) gained in stature from their wartime service and transferred their positions of leadership to civilian life when the war ended (Berlin, Reidy, and Rowland 1998). Angrist (1998) found that the labor-market impact of voluntary military service in more recent years was more favorable for non-whites than for whites.

${ }^{25}$ Of native-born white males aged 20 to 55 who were employed in unskilled occupations in 1860 , $50 \%$ became farmers, and $18 \%$ were artisans by 1880 ; respectively $43 \%$ and $13 \%$ of Union Army veterans who were unskilled workers at the time of enlistment did so. On the other hand, the probability that the unskilled moved up to white-collar occupations was $12 \%$ for the Union Army veterans, and $10 \%$ for the entire native-born white male population. I thank Joseph Ferrie for calculating and providing me with the figures for the white male population based on his sample of individuals linked to the 1860 and 1880 censuses. See Ferrie (2005) for a more detailed description of the sample.

${ }^{26}$ A rough estimate of the probability that unskilled non-veterans moved up to white-collar occupations can be given in the following manner. For this computation, I made some assumptions, including that measures of occupational mobility of the native-born white male population aged 20 to 55 (offered by Ferrie's sample) are the same as those of the entire northern white male population of military age (13 to 43 in 1860); and that the percentage of the unskilled is the same for veterans and non-veterans. Since the percentage of the northern white male population of military age who joined the Union Army was 35\%, and the wartime death rate of the age group 
If Civil War military service had a strong effect on individual veterans' occupational choice after the service, its aggregate impact on the occupational mobility of the population at large should be modest at best. This is because Union Army veterans who survived the war accounted for less than a third of the entire northern male population of military age, and the majority of them had served as private infantrymen whose chances of moving up to white-collar jobs were not greatly different from those of non-veterans. A rough estimate suggests that military service during the Civil War increased the probability that unskilled males of military age moved up to a white-collar job between 1860 and 1880 by $8 \%$ (or $0.8 \%$ points). ${ }^{27}$

Lastly, this study suggests that the labor-market effect of military service differs by the soldiers' socioeconomic backgrounds because of the selective assignment of military positions. In the Union Army, the recruits who possessed better human capital attributes went through more favorable wartime experiences than servicemen with poorer attributes. More skilled and vigorous enlistees were given more opportunities for on-the-job training while in service because they were more likely to be assigned to higher ranks and to noninfantry duties than those with less productive characteristics (Lee 1999). Furthermore, senior-ranking soldiers and non-infantrymen were less likely to be killed by diseases or suffer from illnesses while in service than privates and infantrymen, respectively (Lee 1997, 2003). Since wartime illnesses strongly diminished wealth accumulations and geographic mobility of the recruits (Lee 2005a, 2005b), the overall labor-market impact of rank and duty would be even greater than suggested here, if their indirect effects though health on

was $6 \%$ for the North (Vinovskis 1990), the percentage of the white male population at military age at the end of the war that is accounted for by Union Army veterans is 31\% [(35-6)/(100-6)=31]. Since the percentage of the unskilled who entered white-collar occupations by 1880 was $12.1 \%$ for the Union Army veterans and $10.2 \%$ for the entire white male population, the probability that unskilled non-veterans switched to a white-collar job by 1880 (denoted by $\mathrm{P}_{\mathrm{n}}$ ) is given as $9.4 \%$ by solving the following equation for $P_{n}:(0.31 \times 12.1)+\left(0.69 \times P_{n}\right)=9.4$. Compared to this estimate for non-veterans, the probability of entering a white-collar job for all unskilled veterans $(12.1 \%)$ is $29 \%$ higher; and the probability for the unskilled veterans who had been privates throughout their military service and who had not served on white-collar duties $(10.7 \%)$ is $14 \%$ higher.

27 The estimated probabilities of moving up to white-collar occupations for non-veterans $(9.4 \%)$ and the entire white male population $(10.2 \%)$ suggest that the percentage of the unskilled who entered a white-collar job would have been only $8 \%$ (or $0.8 \%$ points) lower had there been no differences between veterans and non-veterans in occupational mobility. 
other measures of economic status were considered. In this sense, military service in the Union Army widened the disparity in economic mobility between men who possessed different skills and physical strength prior to enlistment. 


\section{References}

Angrist, Joshua. 1990. "Lifetime Earnings and the Vietnam Era Draft Lottery: Evidence from Social Security Administrative Records." American Economic Review 80(3): 313336.

Angrist, Joshua. 1998. "Estimating the Labor Market Impact of Voluntary Military Service Using Social Security Data on Military Applications.” Econometrica 66(2): 249-288.

Angrist, Joshua, and Alan B. Krueger. 1994. "Why Do World War II Veterans Earn More Than Non-veterans?" Journal of Labor Economics 12(1): 74-97.

Berlin, Ira, Joseph P. Reidy, and Leslie S. Rowland, eds. 1998. Freedom's Soldiers: The Black Military Experience in the Civil War. New York: Cambridge University Press.

Bodnar, John. 1985. The Transplanted: A History of Immigrants in Urban America. Bloomington: Indiana University Press.

Costa, Dora L., and Matthew E. Kahn. 2004a. "Forging a New Identity: The Costs and Benefits of Diversity in Civil War Combat Units for Black Slaves and Freemen.” NBER Working Paper No. 11013.

Costa, Dora L., and Matthew E. Kahn. 2004b. "Shame and Ostracism: Union Army Deserters Leave Home.” NBER Working Paper No. 10425.

Ferrie, Joseph. P. 1999. "Yankeys Now": European Immigrants in the Antebellum U.S., 1840-1860. New York: Oxford University Press.

Ferrie, Joseph P. 2005. "History Lessons: The End of American Exceptionalism? Mobility in the United States Since 1850.” Journal of Economic Perspectives 19(3): 199-215.

Fogel, Robert W. 1993. "New Sources and New Techniques for the Study of Secular Trends in Nutritional Status, Health, Mortality, and the Process of Aging." Historical Methods 26(1): 5-43.

Fogel, Robert W. 2000a. Public Use Tape on the Aging of Veterans of the Union Army. Data User's Manual. Military, Pension, and Medical Records 1820-1940. Version M-5. Center for Population Economics, University of Chicago Graduate School of Business and Department of Economics, Brigham Young University.

Fogel, Robert W. 2000b. Public Use Tape on the Aging of Veterans of the Union Army. 
Data User's Manual. U.S. Federal Census Records 1850, 1860, 1900, 1910. Version C-3. Center for Population Economics, University of Chicago Graduate School of Business and Department of Economics, Brigham Young University.

Fogel, Robert W. 2001. Public Use Tape on the Aging of Veterans of the Union Army. Data User's Manual. Surgeon's Certificates 1862-1940. Version S-1 Standardized. Center for Population Economics, University of Chicago Graduate School of Business and Department of Economics, Brigham Young University.

Geary, James W. 1991. We Need Men: The Union Draft in the Civil War. Dekalb: Northern Illinois University Press.

Goldin, Claudia D., and Frank D. Lewis. 1975. "The Economic Cost of the American Civil War: Estimates and Implications.” Journal of Economic History 35(2): 299-326.

Kemp, T. R. 1990. "Community and War: The Civil War Experience of Two New Hampshire Towns." In Toward A Social History of the American Civil War, ed. M. A. Vinovskis, 31-77. New York: Cambridge Univ. Press.

Levine, Peter. 1981. "Draft Evasion in the North during the Civil War, 1863-1865." Journal of American History 67(4): 816-34.

Lee, Chulhee. 1997. "Socioeconomic Background, Disease, and Mortality among Union Army Recruits: Implications for Economic and Demographic History." Explorations in Economic History 34(1), 27-55.

Lee, Chulhee. 1999. "Selective Assignment of Military Positions in the Union Army: Implications for the Impact of the Civil War.” Social Science History 23(1): 67-97.

Lee, Chulhee. 2003. "Prior Exposure to Disease, and Later Health and Mortality: Evidence from Civil War Medical Records." In Health and Labor Force Participation over the Life Cycle: Evidence from the Past, ed. D. L. Costa, 51-88. Chicago: University of Chicago Press.

Lee, Chulhee. 2005a. "Wealth Accumulation and the Health of Union Army Veterans, 1860-1870.” Journal of Economic History 65(2): 352-385.

Lee, Chulhee. 2005b. "Health, Information, and Migration: Post-Service Geographic Mobility of Union Army Veterans, 1860-1880.” NBER Working Paper No. 11207. 
Long, Jason, and Joseph Ferrie. 2005. “A Tale of Two Labor Markets: Intergenerational Occupational Mobility in Britain and the U.S. since 1850.” NBER Working Paper No. 11253.

McPherson, James M. 1982. Ordeal by Fire: The Civil War and Reconstruction. New York: Alfred A. Knopf.

McPherson, James M. 1988. Battle Cry of Freedom: The Civil War Era. New York: Oxford University Press.

Murdock, Eugene C. 1964. “Was It A Poor Man’s Fight?” Civil War History 10: 241-45.

Murdock, Eugene C. 1971. One Million Men: The Civil War Draft in the North. Worcester: The Heffernan Press.

Rorabaugh, W. J. 1986. "Who fought for the North in the Civil War? Concord, Massachusetts, Enlistments.” Journal of American History 73(3): 695-701.

Shannon, Fred, A. 1928. The Organization and Administration of the Union Army, 18611865. Vol. 1. Cleveland: Arthur H. Clark Company.

Thernstrom, Stephan. 1964. Poverty and Progress. Cambridge: Harvard University Press.

Thernstrom, Stephan. 1973. The Other Bostonians. Cambridge: Harvard University Press.

U.S. Surgeon General's Office. 1870. Medical and Surgical History of the War of the Rebellion. Washington, DC: Government Printing Office.

Vinovskis, Maris A. 1990. "Have Social Historians Lost the Civil War? Some Preliminary Demographic Speculations." In Toward A Social History of the American Civil War, ed. M.A. Vinovskis, 1-30. New York: Cambridge Univ. Press.

Wimmer, Larry T. 2003. "Reflections on the Early Indicators Project: A Partial History.” In Health and Labor Force Participation over the Life Cycle: Evidence from the Past, ed. D. L. Costa, 1-10. Chicago: University of Chicago Press. 
Table 1

Results of Logistic Regressions:

Correlates of the Probability of Occupational Change by 1880 for the Unskilled

\begin{tabular}{|c|c|c|c|c|c|c|c|}
\hline \multirow[t]{2}{*}{ Variable } & \multirow[t]{2}{*}{ Mean } & \multicolumn{2}{|c|}{$\begin{array}{c}(1) \\
\text { White-collar } \\
\text { Mean=0.121 }\end{array}$} & \multicolumn{2}{|c|}{$\begin{array}{c}(2) \\
\text { Farmer } \\
\text { Mean }=0.432\end{array}$} & \multicolumn{2}{|c|}{$\begin{array}{c}(3) \\
\text { Artisan } \\
\text { Mean=0.125 }\end{array}$} \\
\hline & & $\partial \mathrm{P} / \partial x$ & P-value & $\partial \mathrm{P} / \partial x$ & P-value & $\partial \mathrm{P} / \partial x$ & P-value \\
\hline Company mortality 1 & 0.205 & $\mathrm{NI}$ & NI & $\mathrm{NI}$ & $\mathrm{NI}$ & $\mathrm{NI}$ & $\mathrm{NI}$ \\
\hline Company mortality 2 & 0.296 & 0.203 & 0.3501 & 0.119 & 0.3915 & -0.192 & 0.2179 \\
\hline Company mortality 3 & 0.175 & 0.293 & 0.2489 & 0.125 & 0.4380 & -0.255 & 0.1548 \\
\hline Company mortality 4 & 0.324 & 0.520 & 0.0368 & -0.050 & 0.7043 & -0.345 & 0.0218 \\
\hline Wounded & 0.276 & -0.114 & 0.3904 & 0.149 & 0.1622 & -0.046 & 0.7397 \\
\hline Illnesses suffered & 0.682 & -0.227 & 0.0577 & 0.165 & 0.1195 & -0.120 & 0.3300 \\
\hline Privates & 0.804 & NI & NI & NI & NI & NI & $\mathrm{NI}$ \\
\hline Corporals & 0.105 & -0.034 & 0.8648 & 0.392 & 0.0190 & -0.085 & 0.6701 \\
\hline Sergeants & 0.073 & 0.582 & 0.0309 & -0.155 & 0.3232 & -0.014 & 0.9533 \\
\hline Officers & 0.018 & 0.841 & 0.0983 & -0.430 & 0.1064 & 0.377 & 0.4339 \\
\hline Infantrymen and combatants & 0.729 & $\mathrm{NI}$ & $\mathrm{NI}$ & NI & $\mathrm{NI}$ & $\mathrm{NI}$ & NI \\
\hline White-collar duty & 0.065 & 1.277 & 0.0000 & -0.379 & 0.0075 & -0.117 & 0.6244 \\
\hline Skilled duty & 0.012 & -0.228 & 0.6758 & 1.013 & 0.0656 & -0.249 & 0.6021 \\
\hline Unskilled duty & 0.181 & -0.097 & 0.5496 & -0.065 & 0.5549 & -0.248 & 0.0903 \\
\hline Musicians & 0.013 & 1.878 & 0.0059 & -0.409 & 0.1947 & 0.593 & 0.2668 \\
\hline Age & 23.829 & -0.247 & 0.0002 & 0.198 & 0.0005 & -0.090 & 0.1814 \\
\hline $\operatorname{Age}^{2} * 10^{-1}$ & 61.032 & 0.044 & 0.0011 & -0.026 & 0.0036 & 0.015 & 0.2233 \\
\hline Natives & 0.814 & -0.025 & 0.8811 & 0.371 & 0.0119 & -0.085 & 0.5616 \\
\hline Tenant farmers & & -0.291 & 0.0137 & 2.638 & 0.0000 & -0.560 & 0.0000 \\
\hline Height 1 & 0.187 & -0.065 & 0.7271 & -0.041 & 0.7702 & -0.142 & 0.3957 \\
\hline Height 2 & 0.182 & 0.016 & 0.9331 & 0.178 & 0.2403 & -0.297 & 0.0648 \\
\hline Height 3 & 0.202 & NI & $\mathrm{NI}$ & NI & NI & NI & NI \\
\hline Height 4 & 0.226 & -0.091 & 0.6105 & 0.364 & 0.0181 & -0.238 & 0.1339 \\
\hline Height 5 & 0.204 & -0.113 & 0.5269 & 0.161 & 0.2637 & -0.212 & 0.2075 \\
\hline Enlisted in 1861 & 0.230 & -0.103 & 0.6819 & 0.196 & 0.3995 & 0.308 & 0.3812 \\
\hline Enlisted in 1862 & 0.348 & -0.245 & 0.2797 & 0.452 & 0.0693 & 0.620 & 0.1046 \\
\hline Enlisted in 1863 & 0.055 & $\mathrm{NI}$ & $\mathrm{NI}$ & $\mathrm{NI}$ & NI & $\mathrm{NI}$ & NI \\
\hline Enlisted in 1864 & 0.250 & -0.448 & 0.0310 & 0.643 & 0.0196 & 0.166 & 0.6127 \\
\hline Enlisted in 1865 & 0.117 & -0.274 & 0.3050 & 0.338 & 0.2221 & 0.333 & 0.3893 \\
\hline New England & 0.109 & -0.404 & 0.0256 & -0.736 & 0.0000 & -0.220 & 0.2828 \\
\hline Mid-Atlantic & 0.321 & -0.029 & 0.8422 & -0.430 & 0.0000 & 0.148 & 0.3396 \\
\hline North East Central & 0.576 & NI & NI & NI & NI & $\mathrm{NI}$ & NI \\
\hline North West Central & 0.076 & -0.095 & 0.6853 & 0.125 & 0.0674 & 0.196 & 0.4885 \\
\hline South & 0.070 & -0.100 & 0.6735 & -0.271 & 0.4801 & 0.189 & 0.4781 \\
\hline $\begin{array}{l}\mathrm{N} \text { of observations } \\
-2 \text { Log L } \\
\text { Chi-square } \\
\text { P-value }\end{array}$ & & & $\begin{array}{l}055 \\
665 \\
0000\end{array}$ & & $\begin{array}{l}3 \\
6.622 \\
6.527 \\
0.0000\end{array}$ & & $\begin{array}{l}3 \\
7.306 \\
5.727 \\
0.0000\end{array}$ \\
\hline
\end{tabular}

Note: The sample is limited to veterans who were linked to the 1880 census and for whom information on all independent variables is given. NI stands for "Not Included." Dependent variable has a value of one if a veteran moved to a better occupation (whitecollar for column 1, farming for column 2, and skilled jobs for column 3), and zero, otherwise. 
Table 2

Results of Logistic Regressions: Correlates of the Probability of Moving Up to White-Collar Occupation by 1880 for Sub-Samples of the Unskilled

\begin{tabular}{|c|c|c|c|c|c|c|c|c|c|c|c|c|}
\hline \multirow[t]{2}{*}{ Variable } & \multicolumn{3}{|c|}{$\begin{array}{l}\text { (1) } \\
\begin{array}{c}\text { Sample of recruits who served for one to } \\
\text { three years }\end{array}\end{array}$} & \multicolumn{3}{|c|}{$\begin{array}{c}\text { (2) } \\
\text { Sample of recruits who served for less than } \\
\text { one year }\end{array}$} & \multicolumn{3}{|c|}{$\begin{array}{l}\text { (3) } \\
\text { Sample of recruits who were under } 28 \text { at } \\
\text { the time of enlistment }\end{array}$} & \multicolumn{3}{|c|}{$\begin{array}{l}\text { Sample of recruits who were } 28 \text { or older at } \\
\text { the time of enlistment }\end{array}$} \\
\hline & Mean & $\partial \mathrm{P} / \partial x$ & P-value & Mean & $\partial \mathrm{P} / \partial x$ & P-value & Mean & $\partial \mathrm{P} / \partial x$ & P-value & Mean & $\partial \mathrm{P} / \partial x$ & $\mathrm{P}$-value \\
\hline \multicolumn{13}{|l|}{ Rank } \\
\hline Privates & 0.781 & NI & NI & 0.900 & NI & NI & 0.796 & NI & NI & 0.834 & NI & NI \\
\hline Corporals & 0.116 & -0.031 & 0.9299 & 0.052 & 0.862 & 0.1976 & 0.113 & 0.017 & 0.9380 & 0.077 & -0.450 & 0.4396 \\
\hline Sergeants & 0.087 & 0.844 & 0.0869 & 0.033 & 0.229 & 0.7606 & 0.075 & 0.537 & 0.0645 & 0.064 & 0.883 & 0.2540 \\
\hline Officers & 0.016 & 2.177 & 0.0818 & 0.015 & -0.119 & 0.9106 & 0.016 & 0.887 & 0.1302 & 0.025 & 0.310 & 0.7846 \\
\hline \multicolumn{13}{|l|}{ Duty } \\
\hline Infantrymen & 0.673 & NI & NI & 0.839 & NI & NI & 0.733 & NI & NI & 0.712 & NI & NI \\
\hline White-collar duty & 0.077 & 1.783 & 0.0023 & 0.031 & 0.777 & 0.3350 & 0.067 & 1.463 & 0.0000 & 0.061 & 0.717 & 0.3690 \\
\hline Skilled duty & 0.010 & 0.000 & 0.9847 & 0.008 & 1.274 & 0.4741 & 0.012 & -0.395 & 0.5023 & 0.011 & 0.649 & 0.6674 \\
\hline Unskilled duty & 0.223 & 0.076 & 0.8028 & 0.110 & -0.002 & 0.9963 & 0.172 & -0.189 & 0.2796 & 0.211 & 0.292 & 0.5048 \\
\hline \multirow[t]{2}{*}{ Musicians } & 0.017 & 2.514 & 0.0549 & 0.012 & -0.019 & 0.9862 & 0.016 & 1.794 & 0.0103 & 0.005 & 17.922 & 0.0744 \\
\hline & \multicolumn{3}{|c|}{$\begin{array}{c}\text { Dependent mean }=0.123 \\
N=813\end{array}$} & \multicolumn{3}{|c|}{$\begin{array}{c}\text { Dependent mean }=0.105 \\
N=736\end{array}$} & \multicolumn{3}{|c|}{$\begin{array}{c}\text { Dependent mean }=0.134 \\
N=2093\end{array}$} & \multicolumn{3}{|c|}{$\begin{array}{c}\text { Dependent mean }=0.079 \\
N=610\end{array}$} \\
\hline
\end{tabular}

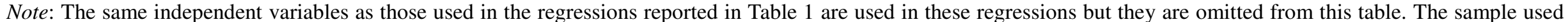

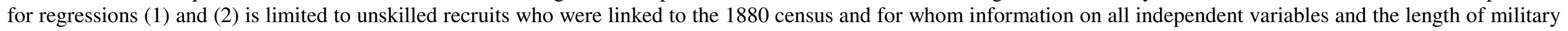
service is given. NI stands for "Not Included." Dependent variable has a value of one if a veteran moved to a white-collar occupation, and zero, otherwise. 
Table 3

Comparison of Simple and Instrumental Variable Estimates of Logistic Regressions: Correlates of the Probability of Moving Up to White-Collar Occupation by 1880

\begin{tabular}{|c|c|c|c|c|c|c|}
\hline Variable & $\begin{array}{l}(1) \\
\text { Mean }\end{array}$ & $\begin{array}{c}\text { (2) } \\
\text { Std. Dev. }\end{array}$ & $\begin{array}{c}\text { (3) } \\
\text { Parameter }\end{array}$ & $\begin{array}{c}(4) \\
\partial \mathrm{P} / \partial x\end{array}$ & (3) $\stackrel{(5)}{\times}(2)$ & $\begin{array}{c}\text { (6) } \\
\text { P-value }\end{array}$ \\
\hline 1. Dummy for higher rank & 0.0902 & 0.2866 & 0.5672 & 0.763 & 0.1625 & 0.0022 \\
\hline $\begin{array}{l}\text { 2.Predicted probability of } \\
\text { higher rank }\end{array}$ & 0.1112 & 0.0358 & 4.8543 & 127.291 & 0.1737 & 0.0052 \\
\hline
\end{tabular}

Note: The same independent variables as those used in the regressions reported in Table 1, except the variables on company mortality and the year of enlistment, are used in these regressions but are omitted from this table. The sample used for the regressions is limited to unskilled recruits who were linked to the 1880 census and for whom information on all independent variables is given. The dependent variable has a value of one if a veteran moved to a white-collar occupation, and zero, otherwise. Row 2 indicates the predicted probabilities of holding a higher rank while in service estimated by the first-stage regression. 
Appendix Table 1

Classification of Military Duties for the Entire Union Army Sample

\begin{tabular}{|c|c|c|}
\hline Category & $\mathrm{N}^{\mathrm{a}}$ & Descriptions of duties ${ }^{b}$ \\
\hline White-collar & $436(1.2)$ & $\begin{array}{l}\text { Recruiter (239), Commander (88), Physician (36), Chaplain (35), } \\
\text { Freedman's Bureau (13), Postmaster (7), Court Marshal (5), Inspector } \\
\text { (4), Board of Labor (3), Probate (1), Teacher (1), Topographer (1) }\end{array}$ \\
\hline Non-manual & $1936(5.4)$ & $\begin{array}{l}\text { Nurse (628), Clerk (332), Orderly (280), Commissary (275), Hospital } \\
\text { (172), Servant (90), Attendant (84), Police (45), Signal (20), Painter } \\
\text { (7), Veterinary (3) }\end{array}$ \\
\hline Skilled & $486(1.4)$ & $\begin{array}{l}\text { Blacksmith (117), Builder (106), Carpenter (99), Engineer (56), } \\
\text { Telegraph (18), Hostler (17), Sawmill (16), Saddler (13), Shipyard } \\
\text { (12), Tailor (11), Printer (7), Other skilled (14) }\end{array}$ \\
\hline Unskilled & $5151(14.5)$ & $\begin{array}{l}\text { Guard (2321), Teamster \& Wagoner (1082), Cook (842), Ambulance } \\
\text { (279), Boatman (220), Laborer (208), Baker (64), Driver (44), Butcher } \\
\text { (37), Herdsman (30), Forager (18), Fireman (6) }\end{array}$ \\
\hline Musicians & $406(1.3)$ & Musicians (406) \\
\hline Combatants & $829(2.33)$ & $\begin{array}{l}\text { Scout (504), Artillery (179), Sharp shooter (32), Garrison (16), Other } \\
\text { combatants (98) }\end{array}$ \\
\hline Detached & $703(1.98)$ & Detached \\
\hline Unclassified & $2121(5.96)$ & \\
\hline Infantrymen & $\begin{array}{c}23443 \\
(65.91)\end{array}$ & \\
\hline
\end{tabular}

Note:

a. The number in parenthesis is the percentage of each category

b. The number of each description of military duty is reported in parenthesis 
Appendix Table 2

Military Positions and 1880 Occupation: Men Who Served at Higher Ranks or on White-Collar Duties, and Who Moved up from Unskilled to White-Collar Jobs

\begin{tabular}{|c|c|c|}
\hline & $\begin{array}{l}\text { Military } \\
\text { Positions }\end{array}$ & 1880 Occupation $^{\mathrm{a}}$ \\
\hline \multirow[t]{3}{*}{ Rank } & Corporal & $\begin{array}{l}\text { Merchant (2), Insurance agent, Locomotive engineer, Physician, Saloon } \\
\text { keeper }\end{array}$ \\
\hline & Sergeant & $\begin{array}{l}\text { Clerk (2), Merchant (3), County treasurer, Hotel keeper, Lawyer, Minister, } \\
\text { Peddler, Policy writer, Physician }\end{array}$ \\
\hline & Officer & Artist, Coal dealer, Merchant (3), Salesmen, Telegraph operator \\
\hline \multirow{10}{*}{ Duty } & Attendant & Lawyer, Merchant \\
\hline & Clerk & $\begin{array}{l}\text { Merchant (4), Justice of the Peace, Lawyer (2), Teacher (2), Telegraph } \\
\text { operator, Saloon }\end{array}$ \\
\hline & Commissary & Appraiser, Teacher (2), Travel agent \\
\hline & Musician & $\begin{array}{l}\text { Auditor, Boarding house keeper, Merchant (3), Clerk, County treasurer, } \\
\text { Express messenger, Saloon keeper, Sawmill owner }\end{array}$ \\
\hline & Nurse & $\begin{array}{l}\text { Banker, Saloon keeper, Commercial traveler, Merchant (2), Land agent, } \\
\text { Stock drover }\end{array}$ \\
\hline & Orderly & $\begin{array}{l}\text { Clerk, Merchant (2), Hotel keeper, Policy writer, Steamboat pilot, Street } \\
\text { commissioner, Freight agent }\end{array}$ \\
\hline & Recruiter & Clerk, Merchant (2), Huckster, Lumber inspector, Minister, Postmaster \\
\hline & Servant & Clerk, Druggist, Real estate speculator \\
\hline & Signal & Physician \\
\hline & Veterinary & Insurance agent \\
\hline
\end{tabular}

Note: a. The number of each occupation, if more than one, is reported in parenthesis. 